\title{
Al-Walā' in Islamic Inheritance Law: Looking for Its Legal Effects
}

Muhammad Habibi Miftakhul Marwa

1 Faculty of Law, Universitas Ahmad Dahlan, Yogyakarta habibi.marwa@law.uad.ac.id

\section{Abstract}

Introduction to The Problem: Slaves and slavery had existed since before Islam preached by Muhammad (PBUH). Islam provides gradual problem-solving methods regarding slavery; one of them is through inheritance. In Islamic Law terms, it called $a l$-wal $\bar{a}^{\prime}$ or liberated slaves. The slave that freed by the master will gain the estate from him. However, slavery is now viewed as merely an academic discourse since it is considered no longer exist.

Purpose/Objective Study: The purpose of this research is to find out the legal standing and legal effect of al- walä' in the Islamic Inheritance Law.

Design/Methodology/Approach: This study is classified as a normative study. The study employed secondary data obtained from the literature review on $a l-w a l \bar{a}$,' and it analyzed descriptively using the conceptual approach.

Findings: The study found that the substance for $a l-w a l \bar{a}^{\prime}$ in the Islamic Inheritance Law of inheritance is to liberate slavery through legal descent-based kinship (nasab hukmī). A person who frees the slaves holds al- walā' right. Accordingly, he has the right to inherit the slave's wealth when the slave dies and does not have any inheritors. Second, al- walä' brings a legal effect on the freed slaves, namely, the person who releases the slave, the slave's left wealth, guardianship, legal competence, and the inheritance itself.

Paper Type: Research article

Keywords: Al- Walā'; Islamic Inheritance Law; Legal Effects

\section{Introduction}

Human, as a living creature, possesses two instincts, namely instinct to survive and to continue life (Muhibbin \& Wahid, 2009). They are given two desires, namely, passion for survival and the lust desire toward the opposite sex for carrying on the descent. Due to those both desires, to preserve their existence, humans tend to gain and own wealth.

Wealth is one of the primary vital needs in human life; accordingly, many people use their best effort to collect and gain it. As a limited resource, wealth is contested by an unlimited number of humans. For some people, wealth is sensitive matters; it may even lead to negative things or evil deeds. Many people do everything that violates religious and state norms to gain wealth (Latif, 2010). Wealth supposed to be used to 
meet the basic human need; however, when human fails to control the way they collect wealth, they may be plunged into evil deeds.

One of the ways to get wealth, and it is an illegal way, is through the process of inheritance. It means that legacy is one of the instruments for distributing wealth in Islam (Dzhofron \& Manzilati, 2016). One of the Islamic inheritance principles states that the inheritance process can only occur when the wealth owner dies. It is even said that Islam only recognizes one form of inheritance law, namely inheritance due to death (Rifenta \& Prayogo, 2019). Death is an essential element of the inheritance process in Islam. Transfer of wealth does not occur as long as the owner of the asset is still alive.

Conversely, the heirs must be ensured still alive. Since the wealth owner dies, a legal issue regarding the inheritance process rises. Rights must be fulfilled immediately by the inheritors, such as funeral costs, paying the deceased person's debt, paying debts relating to alms, kaffārāt, and will. If those rights undistributed in the first place, then inheritance rights will be unavailable.

Interestingly, one of the inheritance criteria in Islamic law named al-walä '. Al- walā is a term used to refer to the slave that freed by his owner; it acts as one of the causes of inheritance. Thus, a person who liberated a slave will obtain the al- walā' right; it is a right to inherit the wealth of slaves when they die as free men. It also their claims to get their ex master's wealth when their liberator has no inheritors. It's interesting to see someone get inheritance because of $a l-w a l a \overline{\text { }}$. Indeed, that slaves' liberation is a historical fact, but a person's right to inherit due to liberating slaves almost no longer exists, considering that slavery has no longer exists today and is merely a textual discourse.

The history of slavery has been known since the Sumerian civilization of Mesopotamia in $3500 \mathrm{BC}$. In this period, the culture of distributing a deceased person's wealth had already been recognized (Luthfi, 2019). Slavery once found among the ancient nations such as Egypt, China, India, Greece, Rome, and is documented in the Torah and the Bible. From the Jew's perspective, the slave is like goods anyone could sell. According to Berkhof (Songgirin, 2018), it is unavoided in Christian history that slavery existed amongst them, where slaves were advised to serve his master with the best possible. Among pre-Islamic communities, a slave held the lowest social strata; they viewed as promising, profitable 'goods' for a transaction. They were treated inhumanly. The concept of freeing slaves was still sporadic. A slave may gain their freedom if their master released them, joined a war, and exhibited the best service for their master (Wahid, 2015).

Slavery practices that occurred during the pre-Islamic period were in contrast with Islamic values. After the emergence of Islam, it regulated a fair treatment and demanded freedom for slaves. Islamic teachings told people to uphold the slaves' rights. The coming of Islam attempted to minimize slavery through al- wala ${ }^{\prime}$, the slave 


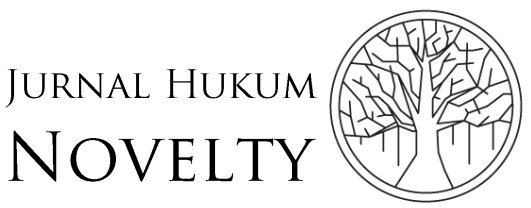

Volume 11, Issue 01, 2020, pp. 56-67
P-ISSN: $1412-6834$

E-ISSN: 2550-0090

liberation. Islamic inheritance transformed the inheritance system that previously did not mention the slave. Thus, Islamic law has provided a foundation of legal equity that meets human rights and dignity.

Such progress could be seen when modern countries began to realize that slavery violates human rights, viewed from the making of the 1926 Slavery Convention. At that time, many states ratified the convention by building a commitment to fight against and eradicate slavery from the social system. It is agreeable that physical slavery has gone; however, from an economic, political, social, and cultural perspective, further study is required to see how this phenomenon grows in modern life.

Concerning inheritance, it is interesting to conduct a more in-depth and comprehensive study on the existence of $a l-w a l \bar{a}^{\prime}$ in the reality of the inheritance distribution in society. From the above perspective, this paper discusses two things: the position of $a l-$ wala $^{`}$ in Islamic inheritance law and its legal consequences.

\section{Methodology}

This study applied a normative legal approach by reviewing literature classified as secondary data. There were three sources of secondary data in this study. First, primary material obtained from legitimate normative sources. Second, secondary material collected from various references related to the problem in the form of books and journals.

The data analyzed descriptively using a conceptual approach and is used as the basis to analyze and make a legal argument to answer legal problems (Dewata \& Achmad, 2010). Regarding conclusion drawing, the study applied the deductive method by concluding the general to the specific statements.

\section{Results and Discussion}

\section{The Legal Effect of $A l$-Walä ' in Islamic Inheritance Law}

Etymologically, al-walā' defined as a help, and it is usually used to show kinship. Terminologically, al-wala ' refers to a relationship in law between the liberator and the one who has been liberated (Saiin, 2016). Al-walā' means waläus śawqah or 'ușūbas sababiyah, it is the 'ușūbah that emerges because of freeing a slave, and walä'ul mu'awalah, it is when a freed slave promises to the people that he can inherit his wealth when he dies (Jamil, 2016).

According to the division of position described by Arto (2012), there are three objects of al-walā'. The first object is the status of al-walā', the role of it in the second place, and the recognition of $a l-$ wala $^{\prime}$ as the third for the improvement of inheritance law brought by Islamic law.

Slaves, in classical fiqh literature, are divided into two types: qinnun and muba'ad. The former refers to slaves who do not have an agreement regarding their freedom. So, 
their status is absolute servitude to his slave owner and becomes slaves forever. The second term, $m u b a^{\prime} a d$, is slaves promised by their master to be freed. There are three terms for muba'ad, namely mudabbar, ummul walād, and mukatab (Luthfi, 2019).

Mudabbar refers to slaves who gain freedom when their master passes away. Ummul walād is a female slave who is impregnated by her master and has delivered the child from that sexual relation. While mukatab, as described in Surah An-Nur: 33, refers to a slave who will only be released by his master if he has paid a sum of money to his master within a determined period of installment. Of the various types of slaves, all slaves are not entitled to inheritance except muba'ad slaves when they die but do not have the right to receive an inheritance (Luthfi, 2019).

Slavery in the pre-Islamic period occurred in many Arab suburbs (Engineer, 2009). Islam itself recognizes slavery as a legacy of slavery from the previous culture. It was understandable because, at that time, the development and implementation of government were carried out using human labor (Roham, 2009). Thus, slavery considered a reality of all society in the classical era. Even though it turned out to be unfavorable and unequal in humanity, none of the religions before Islam was able to end slavery.

From the beginning, Islam did not agree with any form of slavery. All humans, according to Islam, are free. Although at first glance, Islam seems to recognize slavery (Nasution, 2015), but compared to slavery that has happened, Islam dominantly thought on how to release slaves from the bondage of slavery and how to treat them well. If, in the future, there is someone who sues the person's independence status, then the proofing becomes the responsibility of the plaintiff (Siregar, 2018).

Islam has thought that freeing slaves is a noble act. Some of these teachings are liberating slaves as kaffārāt like it has written in several Surah in Al-Quran. Islamic law, in Surah An-Nisa: 92, gives sanction for unintentionally killing the believers and killing infidels accompanied by treaties with freeing the slaves. The liberating slaves as kaffärāt also exist in Surah Al-Mujadilah: 2 concerning zihār, Surah Al-Maidah: 89 regarding payment for breaking the oath, Surah At-Taubah: 60 about the fines for those who are doing sexual intercourse between husband and wife during the day of fasting Ramadan. Liberating slaves also exists in Surah An-Nur: 33 regarding the possibility of the slaves to redeem themselves with mukatab.

Slaves' liberation in Islam was performed gradually to avoid the social effects (contradictions) from people who had enjoyed slavery and had become ingrained in the lives of ignorant peoples (Nasution, 2015). Islamic policy towards slavery substantially shown to reduce enslavement and to open the door of freedom for slaves. So, Islam does not teach about how to enslave but how to free the slaves (Palawa, 2016). The liberation itself, except if it related to certain sanctions, is considered as mandūb in Islamic law; if it is done, it will be rewarded, and there will be no sin for those who leave it (Siregar, 2018). 


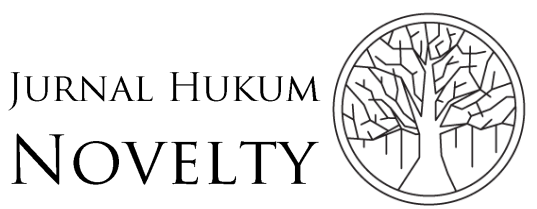

Volume 11, Issue 01, 2020, pp. 56-67
P-ISSN: $1412-6834$

E-ISSN: 2550-0090

Before Islam came, there had been an inheritance system that carried out following the development of the community. However, the past inheritance system tends to be discriminative since it is still power and rule-oriented (Arsal, 2012). In this age of ignorance (i.e., jāhiliyyah), the distribution of inheritance was carried out for three reasons: kinship relation (nasab), an oath of allegiance (al-hilf), and an adoption (altabannīy) (Muhibbin \& Wahid, 2009).

Kinship is a nasab relationship between persons and their inheritors due to birth. However, the inheritance culture in pre-Islam does not include female kinship. Only they who have physical strength, be able to fight, and maintain the honor of their tribe, will get the inheritance. This fact caused children and women unable to receive an inheritance because they did not meet these qualifications. They failed to play the role of independent figures in the social, economic, and political fields. Female relatives were considered a burden on family life (Saleh, 1972). The history stated that the female born baby was buried alive since she was viewed as a family disgrace. Therefore, Inheritors during this era were based on kinship consisting of sons, brothers, uncles, and growing children. Thus, Islam abolished this culture and has elevated women to be included as inheritors whenever they meet the nasab relationship (Mehregan, 2016; Siddique, 2017).

Second, the oath of allegiance is a pledge of loyalty between parties, and it has a legal force to defend each other's soul, body, and honor. The commitment of the promise does not require kinship or marriage relationships. Such legal effects also implicated in inheritance; if one of the pledge parties dies, the other party will get the right to inherit the wealth. The oath itself described in a famous pre-Islamic notion, "damiy damuka, wa hadmīy hadmuka, wa tariśunìy wa aris̉uka, wa tațlubu bìy wa ațlubu bika." This notion means that "my blood is your blood, my ruin is your ruin, you inherit me, and I inherit you, this oath binds me and you" (Karim, 2017; Zubaidi, 2017).

The third reason for inheritance distribution is an adoption. The adopted persons, if they already an adult and their adopted father die, they will inherit the properties of their father. However, Islamic inheritance does not make adopted children the heirs of their adoptive parents, but only has the right to receive compulsory testaments (AlHamawi, 2007; Al-Hasan, 2012).

Islamic inheritance law answered the problems practiced by pre-Islamic civilization, such as the Persians, Romans, and Greeks. According to Hazairin (Suparman, 2014), there are characteristics of Islamic inheritance law, namely:

1. The children of the testator, together with the parents of the testator, are becoming the heirs.

2. If the inheritor dies without heirs, the parents and brother or sister will be the heirs.

3. Husband and wife can inherit each other. 
The characteristics of the Islamic inheritance system above are improvements and changes from inheritance principles that were in effect before Islam came. There are at least two universal principles in Islamic inheritance, namely the principle of justice and the principle of humanity. The principle of justice is applied in the form of equal rights and obligations between men and women as obtained by their uses. Although the composition of men and women with a ratio of 2:1 seems discriminatory against women, it has a reasonable base. In essence, men have more obligations than women, such as providing a living, working, and protecting and being a family leader, while women only support themselves (Al-Mabruri, 2017). Munawir Sjadzali, with his concept of humanity, views that the 2:1 ratio of inheritance right is not absolute. When the fact shows that the son has enjoyed many of the parent's wealth, while the daughter is in need, the distribution of inheritance could be done flexibly (Permana, 2018).

Meanwhile, Hazairin attempts to present the bilateral inheritance system by reducing the priority for men to prevent others from inheritance (Sakirman, 2016). Islamic Inheritance Law is even deemed able to remove trait differences in men and women (Musyafaah, 2017). So this comparison does not mean that Islamic inheritance is discriminatory to women but based on the responsibilities imposed on the husband.

The implementation of humanity principle also reflected in the process of transferring the inheritors' wealth to their heirs. The slave who initially did not have independence over him has full authority over his soul and body after being freed. This reflection called humanization in inheritance. It has proven clearly in Surah AlBalad: 11-13, where Allah Almighty commands Muslims to liberate their slaves.

Slaves owned by someone then freed from slavery and left an inheritance without having an heir except the former master, then the slave owner has the right of al-walä to obtain heirlooms. Al-walā' in Islamic inheritance law is an heir as long as it does not have żawil furūḍ and așābah. Thus, a person has the right to become an heir because he has freed the slaves, and the freedman (slave) is considered to have a kinship relationship legally. The concept is in line with the causes of inheriting from heirs in classical Fiqh: kinship relationship, legal marriage, the same faith, and alwalā' (Lubis \& Simanjutak, 1996).

Even though al-walā' is now seen to be gone, but in the context of classical Islamic inheritance law, the status of slaves and the liberating slaves are different. Among the barriers of inheritance rights, slavery is one of these hindrances (At-Tuwaijiri, 2016). Thus, Muslim testators are not allowed to make a will for slaves (Sukarna \& Hambali, 2017). The intention of inheritance only occurred when slaves are liberated.

If slavery can disqualify the heir's right to receive the inheritance, then al-walō' is the reason for the transfer of legacy due to kinship as a result of liberating the slaves (Sullivan, 2019).Al-walā' is the reason for inheriting mutual inheritance. The meaning of the $a l$ - walà ${ }^{\prime}$ relationship is that the slave owner will inherit his freed-slave, but not 


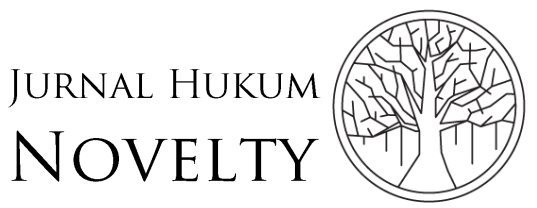

Volume 11, Issue 01, 2020, pp. 56-67
P-ISSN: $1412-6834$

E-ISSN: 2550-0090

otherwise, the freed-slaves could not inherit their former master when they die. Even though the slave and the slave owner do not have a related relationship, they are considered as relatives based on heredity after the slaves get their freedom.

Freeing slaves is a part of social worship for every Muslim (Songgirin, 2018), while at the same time applying mutual assistance (at-ta'āwun) between one and another. It is mutual help given by the slave owner to the slaves. This concept is an effort to create a sense of social concern for fellow human beings based on humanity. The mutual help is also realizing al-maqāșid al-syarī'ah in accommodating the benefit of humankind through two dimensions: the world and the hereafter.

According to Asy-Syatibi (in Sahroni \& Karim, 2015), there are five general principles (al-kulliyyāt al-khamsah) in the al-maqāṣid al-syarī'ah. Those five are, namely, protecting religion, protecting the soul, protecting the intellect, protecting the descendant, and protecting the treasure. The five preservations cover all of the Islamic inheritance practices. The practicing of Islamic inheritance considered as half of the human affairs, so applying the law is preserving the religion (hifz al-dīn). Stating the murder as a barrier for gaining the inheritance could be placed in keeping the soul (hifz al-nafs). Learning and teaching faräid science in Islamic law could be an effort to protect the human mind or knowledge. It is like what Prophet Muhammad said as narrated by Ad-Dāruquțī, "Learn the inheritance and teach it to humans for it is half of knowledge and will be forgotten. It is the fundamental science that will be revoked from my followers (Al-Daruqutni, 2004). Transferring the wealth to the heirs is an effort to protect the family and all of the offspring (hifz al-nasl). It is providing sufficient living guarantees for the heirs by taking advantage of the wealth left by the inheritors. The last principle in Islamic inheritance is protecting the properties (hifZ al-māl) that realized through the fair distribution of properties according to the Sharia law. This provision confirms that Islam only gives and distributes treasuries to those who have the right (Daud, 2018; Suwarna, 2018).

Meanwhile, according to Sa'adah, the concept of al-maqāșid al-syarīah in Islamic inheritance law is dominated to maintain offspring (hifz al-nasl) and wealth (hifz al$m \bar{a} l)$. At the same time, the level of its needs is secondary (al-hājiyyāt), not primary (al-ḍarüriyyāt) (Sa'adah, 2015).

It is very relevant and natural for someone who frees slaves get al- walā' right of his/her ex-slave. It was narrated by Muhammad, "The right of al- walā' is only given to those who have freed their slaves" (Al-Bukhari, 1987; Muslim, 1991). Also, from his saying, "al-walā' is a legal kinsman who should not be sold and granted" (Al-Hakim, 2002). From both hadiths, Islam has developed and changed the relational pattern between a master and the slave, from being viewed as worthless and treated inhumanly to having a family-like relationship (Fatkhi \& Lisalam, 2018). 


\section{Legal Consequences of Al-Walā' in Islamic Inheritance Law}

As a legal act, freeing slaves results in an inevitable legal consequence. If legal action does not bring legal consequences, it cannot be called a legitimate fact, but as an ordinary social fact (Sarong, 2016). Various legal effects emerge because of freeing a slave. It may affect the freed slaves, the masters who voluntarily liberate their slave, and the deceased former slave's inheritance.

\section{Legal consequences for slaves and their liberation}

Islam has declared that all human beings have free souls and unallowed to facilitate the enslavement. Imam An-Nawawi said (Luthfi, 2019), "basically, the child of Adam is independent." So the original status of a human being is freeman unless there is evidence on the contrary.

Slaves who have been freed by their owners will get the status as a free and independent person. According to Al-Hawawi Al-Hanafi (Luthfi, 2019), freedom for humans is the right of Allah. If it is known that freed-slaves are being enslaved again by another, it is then classified as tyranny and violating God's prerogative.

The known legal consequence in Islamic inheritance is the emerging of al-walā'status. When the liberated-slaves die and leave no heirs than their ex-master who freed them will be placed as their inheritors. Their previous master will receive the wealth of freed-slaves based on the legal kinship relationship through al-walā’status.

There is a verse of the Al-Quran and hadith that explain great virtue and reward for anyone who liberates slaves. In Surah Al-Balad: 11-13, "but he has not broken through the difficult pass. And what can make you know what is the difficult pass? It is the freeing a slave". Freeing slave has two meanings, according to Al-Fauzan, which are releasing the slave status directly by the master or another person who buy the slaves and freeing them after. The second meaning is releasing slaves from war prison by paying the ransom (Al-Fauzan, n.d.).

Besides, Islam also gave much motivation to his followers to liberate his slaves. Islam strictly regulates the practice of slavery, even with human accountability in the hereafter. Prophet Muhammad said as it narrated by Tirmidhi, "whoever is a Muslim who liberates a Muslim slave, then his deeds will be releasing himself from the fire of Hell" (Al-Tirmidzi, 2005). Liberating slaves means restoring human beings as being free as the original. So, freeing the slaves makes the perfect degree of humanity.

Al-walā' is a legal implication for freeing the slaves. When they were gone and left the estate, their previous owner will inherit what they left behind (their wealth) during the absence of their heirs. This legal implication is like what Prophet Muhammad said, as narrated by Bukhari and Muslim, "The right of al-walā' is only given to the person who has already freed his slave" (Al-Bukhari, 1987; Muslim, 1991). However, it is highly noted that this right only available with the death of the freed-slaves. The hadith also shows that al-walā's relationship only one way right. It means, only the 


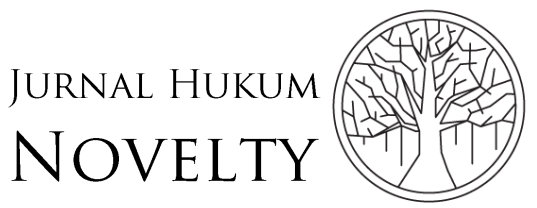

Volume 11, Issue 01, 2020, pp. 56-67
P-ISSN: 1412-6834

E-ISSN: 2550-0090

slave liberator will get the al-walā' ${ }^{\prime}$ ight. The right does not belong to the freed-slaves when their ex-master dies.

\section{The legal consequence of the freed slaves' wealth}

The legal status of the wealth left by the owner is based on the main pillars of Islamic inheritance. One of these main pillars is wealth that abandoned by its owner after his/her death. Thus, the existence of the properties is essential so that the inheritance could be appropriately shared. So, it is the must that these pillars exist, for it has formalized in Fiqh that the main components are something that must present in every problem (deed) discussed. If one of the pillars does not exist, then the act is considered invalid or imperfect (Muhibbin \& Wahid, 2009).

The legal status of the wealth owned by freed slaves still causes dissent among the Islamic jurists, whether it belongs to the person who set them free or to the slaves themselves. The first opinion based on the Ibnu Mas'ud narration that the wealth belongs to the master. Meanwhile, the second opinion based on the Ibnu Umar narration from the Prophet Muhammad, he said, "Whoever freeing the slaves who have the properties, then the features still belongs to them, except when their master requires the wealth will be his" (Majah, 2009).

Leaning to the first opinion is likely appropriate, for it will fulfill the inheritance practice when the slaves die. If the properties taken by the masters after freeing the slaves, then they could not give any to the master when they die. Therefore, the application of al-walā' right within Islamic inheritance cannot happen, because the wealth as a pillar is none.

In another case, if a person dies without having any inheritor at all, his/her asset could be handed over to bait al-māl for the public interest. This case also occurs if the liberated-slaves has no heirs at all, not even their ex-master who has al-walä 'right. Bait al-māl is an institution that has the task of handling the state's property. In the context of the Civil Code, bait al-māl could be referred to as Balai Harta Peninggalan (BHP) (Asyhadie, 2018).

\section{Legal consequences of guardianship}

Guardianship, according to Article 1 of the Indonesian Compilation of Islamic Law (i.e., Kompilasi Hukum Islam, abbreviated as KHI), refers to the authority granted to a person to carry out a legal action as a representative for the interests and on behalf of the person he represents. In the slaves' context, guardianship of freed-slaves is under the control of his master as the person who freed him (Al-Mabruri, 2017). However, the freed-slaves will have their status changed, from legally incompetent to legally competent. After the slaves liberated, the guardianship does not apply in the inheritance distribution context under Islamic law. The personal nature of Islamic inheritance is stated in the Surah An-Nisa: 7, which explains that the share of each heir has been determined individually. 


\section{Conclusion}

Islamic Inheritance Law, as an embodiment of Islamic teachings, is aimed at clearing any deviation regarding inheritance distribution. Spirit of Islam, as stated in the AlQuran and the hadith, speak a lot about slaves and slavery. It aims to eradicate slavery by giving freedom to slaves. Islam teaches its followers to treat the slaves well in all aspects. Freeing slaves is a part of maqāșid al-syarīah, which aims to bring benefit for humans by protecting religion, life, offspring, and wealth.

Al-walä', as a part of slave liberation, is still relevant to a current context, especially in the field of Islamic inheritance, either it is done by an individual, a group, or a state. Accordingly, in the Islamic Inheritance Law, freeing slaves brings legal consequences. For the freed-slaves, once they are freed, they become a testator, and the person who releases them gain al-walä' right to be their inheritor. Regarding assets left by the slaves, it could be inherited by the rightful inheritor. Guardianship does not apply in the inheritance since the former slave possesses a right that is equal to each other.

\section{References}

Al-Bukhari, A. A. M. I. I. (1987). Șaḥịh Al-Bukhārī (M. D. Al-Bugha, Ed.). Beirut: Dār Ibn Kasīir.

Al-Daruqutni, A. ibn U. (2004). Sunan Al-Dāruquțīy (1st ed.; S. Alarnaut, H. A. M. Syalabi, \& S. Allaham, Eds.). Beirut: Al-Resalah Publisher.

Al-Fauzan, S. (n.d.). Tafsīr juz 'amma. Cairo: Al-Dārul 'Ālamiyyah.

Al-Hakim, A. A. M. I. A. (2002). Al-Mustadrak 'ala Al-Ṣahịhain (M. Abd Al-Qadir, Ed.). Beirut: Dar al-Kutub al-Ilmiyah.

Al-Hamawi, U. (2007). Al-Tabannīy wa musykilat al-luqațā’ wa asbāb śubūt al-nasab: Dirāsah fiqhiyyah ijtimā'iyyah muqāranah. Majallah Jāmi'ah Dimasyq Lil 'Ulūm Al-Iqtișādiyah Wa Al-Qanūniyah, 23, 511-534. Retrieved from https://bit.ly/3dKra93

Al-Hasan, S. A. (2012). Hukm al-tabannīy fì al-Islām. Dauriyah Al-'Ulūm Wa Al-Buhūss Al-Islämiyah, 4, 1-10. Retrieved from http://www.sustech.edu/staff_publications/20120911053033565.pdf

Al-Mabruri, M. N. U. (2017). Keadilan pembagian harta warisan perspektif hukum Islam dan Burgerlijk Wetboek. Al-Mazahib, 5(1), 111-131. Retrieved from http://ejournal.uin-suka.ac.id/syariah/almazahib/article/view/1394

Al-Tirmidzi, A. I. M. I. I. I. S. (2005). Sunan At-Tirmidzī (S. J. Al-Attar, Ed.). Beirut: Dār al-Fikr.

Arsal, A. (2012). Kewarisan dalam perspektif Al-Qur'an (Mengungkap filosofi porsi bagian laki-laki dan perempuan 2:1). Al-Hurriyah, 13(1), 19-42. Retrieved from http://ejournal.iainbukittinggi.ac.id/index.php/alhurriyah/article/view/580

Arto, A. M. (2012). Peradilan agama dalam sistem ketatanegaraan Indonesia: Kajian historis, filosofis, politis, yuridis, futuristis, dan pragmaatis. Yogyakarta: Pustaka Pelajar.

Asyhadie, Z. (2018). Hukum keperdataan (dalam perspektif hukum nasional, hukum perdata (BW), hukum Islam, dan hukum adat) (1st ed.). Depok: Rajawali Press.

At-Tuwaijiri, M. bin I. bin A. (2016). Ensiklopedi Islam kaffah (6th ed.; M. Y. Harun, Ed.). Surabaya: Pustaka Yassir.

Daud, Z. F. M. (2018). Menyoal rekonstruksi maqashid dalam pembaharuan hukum 
kewarisan Islam. Jurnal Ilmiah Islam Futura, 18(1), 1-33. https://doi.org/10.22373/jiif.v18i1.2843

Dewata, M. F. N., \& Achmad, Y. (2010). Dualisme penelitian hukum normatif \& empiris (1st ed.). Jakarta: Pustaka Pelajar.

Dzhofron, D., \& Manzilati, A. (2016). Identifikasi maqashid syariah pada pembagian waris (Studi kasus pada warga lembaga dakwah Islam Indonesia di Kota Malang). Jurnal Ilmiah Mahasiswa FEB Universitas Brawijaya, 5(1), 1-12. Retrieved from https://jimfeb.ub.ac.id/index.php/jimfeb/article/view/3404

Engineer, A. A. (2009). Islam dan teologi pembebasan (5th ed.). Yogyakarta: Pustaka Pelajar.

Fatkhi, R. M., \& Lisalam, R. H. (2018). Membumikan HAM mengikis perbudakan (Kajian mawdûûî terhadap hadîts-hadîts perbudakan). Refleksi, 17(2), 151-168. https://doi.org/10.15408/ref.v17i2.10203

Jamil, M. (2016). Nasab dalam perspektif tafsir ahkam. AHKAM : Jurnal Ilmu Syariah, 16(1), 123-130. https://doi.org/10.15408/ajis.v16i1.2902

Karim, N. S. (2017). Hirmān al-mar’ah min al-mïrās fi al-'urf al-Lībīy min al-manzūur alqibalīy wa al-fiqh al-Mālikīy. Islamic State University of Maulana Malik Ibrahim.

Latif, M. A. (2010). Ahli waris pengganti (Studi komparasi menurut kompilasi hukum Islam dan menurut Hzairin). Varia Peradilan, 292, 33-51.

Lubis, S. K., \& Simanjutak, K. (1996). Hukum kewarisan Islam (Lengkap \& Praktis). Jakarta: Sinar Grafika.

Luthfi, H. (2019). Budak dalam literatur fiqih klasik (Pertama; M. Marfuah, Ed.). Jakarta Selatan: Rumah Fiqih Publishing.

Majah, I. (2009). Sunan Ibn Mājah (S. Al-Arnaut, Ed.). Damaskus: Dār ar-Risālah.

Mehregan, A. (2016). Islamo-Arabic culture and women's law: An introduction to the sociology of women's law in Islam. International Journal for the Semiotics of LawRevue Internationale de Sémiotique Juridique, 29(2), 405-424. https://doi.org/10.1007/s11196-016-9467-8

Muhibbin, M., \& Wahid, A. (2009). Hukum kewarisan Islam sebagai pembaharuan hukum positif di Indonesia (Pertama). Jakarta: Sinar Grafika.

Muslim, A. H. (1991). Sahịhh Muslim (1st ed.). Cairo: Dār Al-Hadīs.

Musyafaah, N. L. (2017). Filsafat kewarisan dalam hukum Islam. Al-Qanun, 20(1), 56-76. Retrieved from http://jurnalfsh.uinsby.ac.id/index.php/qanun/article/view/550

Nasution, A. S. A. (2015). Perbudakan dalam hukum Islam. AHKAM: Jurnal Ilmu Syariah, 15(1). https://doi.org/10.15408/ajis.v15i1.2852

Palawa, A. H. (2016). Api Islam Syed Ameer Ali: Perdebatan atas wacara poligami, budak, dan eskatologi. Toleransi: Media Komunikasi Umat Beragama, 8(1), 97-116. Retrieved from http://103.193.19.206/index.php/toleransi/article/view/2473

Permana, S. (2018). Kesetaraan gender dalam ijtihad hukum waris di Indonesia. AsySyari'ah, 20(2), 117-132. https://doi.org/10.15575/as.v20i2.3210

Rifenta, R., \& Prayogo, T. I. (2019). Nilai keadilan dalam sistem kewarisan Islam. Al-Manahij: Jurnal Kajian Hukum Islam, 13(1), 111-127. https://doi.org/10.24090/mnh.v0i1.2117

Roham, A. (2009). Ensiklopedi lintas agama (1st ed.). Jakarta: Emerald.

Sa'adah, S. L. (2015). Maqashid al-syariah dalam hukum kewarisan Islam. Al-Ahwal, 7(1), 125-146. Retrieved from https://adoc.tips/maqashid-al-syari-ah-dalamhukum-kewarisan-islam.html 
Sahroni, O., \& Karim, A. A. (2015). Maqashid bisnis \& keuangan Islam : Sintesis fikih dan ekonomi (1st ed.). Jakarta: Rajawali Press.

Saiin, A. (2016). Menelaah hukum waris pra-Islam dan awal Islam serta peletakan dasar-dasar hukum kewarisan Islam. Al-Ahwal: Jurnal Hukum Keluarga Islam, 9(1), 125. https://doi.org/10.14421/ahwal.2016.09108

Sakirman. (2016). Hukum waris Islam berbasis gender. Akademika Jurnal Keagamaan Dan Pendidikan, 12(2), 48-55. Retrieved from http://ejournal.kampusmelayu.ac.id/index.php/akademika/article/view/13

Saleh, S. (1972). Women in Islam: Their status in religious and traditional culture. International Journal of Sociology of the Family, 2(1), 35-42. Retrieved from https://www.jstor.org/stable/pdf/23027836.pdf?refreqid=excelsior\%3A1f59 9f7c4d5d1fae1346e8831e499489

Sarong, A. H. (2016). Hukum Islam dan Sistem pengangkatan anak di Indonesia. Yogyakarta: Kaukaba Dipantara.

Siddique, H. M. (2017). An appraisal to the status of woman in pre and post Arabian Peninsula with specific reference to her marital rights. Zia-E-Tahqeeq, 7(13), 1940. Retrieved from https://bit.ly/39uhqws

Siregar, A. S. (2018). Politik hukum syarak terhadap perbudakan. Jurnal Al-Mabhats, 3(2). Retrieved from https://ejurnal.iainlhokseumawe.ac.id/index.php/almabhats/article/view/235

Songgirin, A. (2018). Relevansi al-wala' dalam membela nilai-nilai kemanusiaan perbudakan. Rechtsregel, 1(2), 255-274. Retrieved from http://www.openjournal.unpam.ac.id/index.php/rjih/article/view/2217

Sukarna, K., \& Hambali, J. K. (2017). Implementas hak atas ahli waris anak kandung non muslim dalam perspektif hukum Islam yang berlaku di Indonesia. Jurnal Ius Constituendum, 2(2), 170. https://doi.org/10.26623/jic.v2i2.659

Sullivan, J. (2019). Kajian hukum sebab-sebab mendapat dan tidak mendapat warisan menurut hukum waris Islam. Lex Privatum, 7(3), 87-94. Retrieved from https://ejournal.unsrat.ac.id/index.php/lexprivatum/article/view/25915/255 57

Suparman, E. (2014). Hukum waris Islam dalam perspektif Islam, adat, dan BW (4th ed.). Bandung: Refika Aditama.

Suwarna, S. D. (2018). Fiqih mawaris (syariat kewarisan) di Indonesia. Jurnal Syariah Hukum Islam, 1(2), 93-107. Retrieved from journal.iaialmawar.ac.id/index.php/JSHI/article/view/147/49

Wahid, A. H. (2015). Perbudakan dalam pandangan Islam hadith and sirah nabawiyah: Textual and contextual studies. Nuansa, VIII(2), 141-205. Retrieved from https://ejournal.iainbengkulu.ac.id/index.php/nuansa/article/view/392

Zubaidi, A. (2017). Al-Huqūq al-māliyah fì surah al-Nisā: Dirāsah Mauḍ̄'iyyah. Üniversité Elchaid Hamma Lakhdar - El-Oued. 